\title{
Border Check and Security from the Perspective of Travel Document Forgery Before and Following Schengen ${ }^{1}$
}

\section{BALLA József ${ }^{2}$}

The components of border check have a significant impact on the safety of a country or a region. The composition of border traffic by nationality and the security of travel documents from a travel document protection point of view, basically, determine the risk classification/insecurity of a particular border crossing point. Those travel documents which have lower travel document protection become subject to official document forgery in greater numbers. The detection of these illegal acts depends on the preparedness of the person carrying out the control which also means that this person is the key to success.

Keywords: border traffic, border check, security, forgery of official documents

In the course of my research entitled Studying the cause and effect relationship between travel document forgery methods and border check technologies, 1989-2016, conducted in the framework of the Public Services and Public Administration Development Operational Programme, it was my intention to study, analyse and evaluate the chosen topic through the wide scale application of scientific research methods, through setting both organisational and professional, furthermore, personal objectives.

It was my headline target to study the cause and effect relationship between the composition of passenger flows by nationality, travel document forgery rates and methods, moreover, applied border check technology. Based on my almost two-decade-long border policing professional past, I believe that the modifications made in the components of border check have a significant impact on the number and composition of travel document forgeries. Beyond this, they also influence the number of controls itself which have such a content that ensures the opportunity of detection. It is not sufficient to use such travel documents which are properly protected by security features if control technologies do not necessitate their inspection or are not able to inspect them.

The work was created in commission of the National University of Public Service under the priority project PACSDOP2.1.2-CCHOP-15-2016-00001 entitled "Public Service Development Establishing Good Governance" in the István Egyed Postdoctoral Program.

2 BALLA József, PhD, Police Colonel, National University of Public Service, Faculty of Law Enforcement

https://orcid.org/0000-0002-6113-5350, balla.jozsef@uni-nke.hu 
While studying and analysing source materials, I came to the conclusion that the topic has not been processed on an academic level in Hungary. It has several reasons but the main difficulty might lie in the lack of numerical data for those who would like to conduct established and factual analyses.

Such a reliable database, which meets all professional/analytical needs and allows to study all correlations, has been available since 2010 in the form of the Hungarian National Complex Document Register System ${ }^{3}$ (NEKOR) which enables analyses based on about 52 aspects and their combinations (through cross-filtering). Considering the years prior to 2010, it is difficult to search for data as regards methods since neither the Border Guard used to have, nor the Police has reporting obligations related to this kind of data towards the Hungarian Central Statistical Office (hereinafter: HCSO). The passenger and vehicle traffic are searchable in the HCSO's database but the distribution of the detected document forgeries is not even visible according to e.g. the method, perpetrator's nationality, nationality of the used travel document, destination, direction, border crossing point.

Under the aegis of the Border Guard, half-yearly and yearly documentations/reports on official document forgery were issued in a printed form but with the increasing penetration of IT systems, their compilation has been driven to the background, in addition, their data content has had the mentioned deficiencies. Basically, the yearly reports contained a minimum quantity of figures when making a comparison with the previous year's official document forgery statistics what is not suitable for conducting analyses. Data collection is primarily enabled by those electronic databases which can be found at the Documentation Division and Division for Border Policing and Compensation, Border Policing Department, Directorate General for Law Enforcement and the Hungarian National Police Headquarters but in many cases, these are also incomplete and data are not filed. I compiled the table summarising official document forgery methods in the period considered with the help of these sources. Due to the 'difficulties' related to the source material, I have decided to consider it a special and unique objective to keep the specified time span related to the chosen topic in a systematic study for posterity, in addition, to provide those researchers who are committed to this topic with such a work of scientific value that can be considered a reference work.

According to the current policing terminology, border controls basically have two essential components, namely, border surveillance and border check. ${ }^{4}$ One might believe that in Hungary, the expression 'border policing' has become an 'established' term as part of the European integration process, and as a result of the access to the Schengen Area because it has been used since the merger between the border surveillance and border traffic area of expertise in 2004, mainly, for the current, still active professional police

\footnotetext{
Hungarian National Complex Document Register System (NEKOR): The IT system of the Police which contains the description of the security features of genuine, fake and forged travel, identity and other entitlement documents, furthermore, information related to official document forgeries including their visualisation.

4 György Ritecz's interpretation is obvious when he states the following in his book Migration at the Beginning of the $21^{\text {st }}$ Century: "In practice, it is usually forgotten that border control includes risk analysis and criminal investigations too beyond border traffic control and border surveillance." Ritecz (2017) 211.
} 
forces. On the contrary, the 110-year-long past of the border police is proven; its written source is the Border Policing Handbook ${ }^{5}$ published in 1907 which can be considered a collection of laws and regulations related to immigration, emigration and passport issued by the Hungarian Royal Border Police.

The following argument/explanation can be accepted as one of the concise wordings regarding the establishment of the Hungarian Royal Border Police: "Over the past years, the level of emigration has increased to a truly worrying extent, and the immigration of persons living in poverty arriving in great numbers from neighbouring countries has led the Government to establish police headquarters at the borders which keep an eye on and, if applicable, prevent both emigration and immigration."6 Its task had three purposes: to conduct passport and travel document control at the border inspection posts (crossing points) on those parts of the country where there is passport obligation, to issue travel documents and collect data related to border traffic. ${ }^{7}$

It is an important aspect to establish what kind of cause and effect relationship there is between border traffic and border check. Many people use them as a single term but it is by far not correct. Border traffic is generated by people's movement which can be considered an effect. In my view, with regards to the main components of border traffic - certain expressions, of course, have already lost their relevance/substance - the following wording is still acceptable today: "Border traffic means the entry and exit of international passengers, border crossing by vehicles and consignments at international border crossing points, border crossing points between two states or opened for local border traffic. The traffic of those civil aircrafts and their passengers which fly over the People's Republic of Hungary's airspace and do not land on its territory, moreover, domestic traffic on roads crossing state border, border roads and waterways specified in international agreements, furthermore, border crossings related to land-use on the territory of another state do not constitute border traffic." There is another significant aspect beside the desire to get to know other regions, countries which leads to border control: it is the existence of the particular state itself. If state borders were not the basis of state sovereignty as a line (border line) indicating the physical borders of the state territory, it would not have a significance who and in how high numbers cross them. Due to the fact the one element of the state's existence is that the arriving and leaving persons shall cross the state borders (under controlled conditions), this also leads to border control. In these two contexts, border traffic appears as an effect. However, when it is studied in terms of border check, then border traffic is the cause of the necessity of border control, i.e. of border check as an effect. The components of border check are highly dependent on the state's interests, including its security and safety, as well.

Pavlik-Laky (1907)

Pavlik-Laky (1907) Introduction.

1905. 91.000 sz. B. M. r. a határrendőrségről szóló törvény életbelépéséről és végrehajtásáról. 1905. 91.000 számhoz utasítás a határrendőrségről szóló törvény végrehajtása tárgyában.

8 A Magyar Népköztársaság Belügyminiszterének 30/1977. számú Parancsa a Határforgalom Ellenőrzési Szabályzat kiadásáról, Budapest 1977. évi október hó 26-án. 
At the turn of the $19^{\text {th }}$ century, it had to be taken into account that, primarily, merchants travelled significant distances and crossed state borders given their profession. Agriculture and livestock farming used to be the primary sources of livelihood and economic growth which also used to be one of the significant components of border traffic. Until the beginning of industrialisation, trade routes were basically river routes which indicated a location-bound situation. Through the upgrade of road and rail infrastructure, the role of waterways decreased and a significant part of it was relocated. In addition to the infrastructural development, the penetration of vehicles, their availability and the increase in their numbers made border traffic a 'multi-actor' environment, and in parallel, it also started to increase. Tourism also appeared as a factor generating border traffic beside trade activities. But it must be added that till the mid-19 ${ }^{\text {th }}$ century, it was mainly considered to be the wealthy persons' privilege, and it was not 'accessible' by everyone for the purpose of recreation, leisure or travel related to hunting.

Selective $^{9}$ (separation of persons subject to control for example, by nationality - based on risk analysis) and differentiated ${ }^{10}$ (determines the content and components of control) controls play an important role in the 'development' process of border check. Risk classification appropriate to the level of security ensures that controls hinder passengers insofar as it is necessary, the onward journey of well-intentioned people is granted, and offenders are apprehended.

Selective control is supported by the up-to-date information technology too which, for example, contributes to criminal profiling through predictive character and habit analysis. Based on this criminal profile, it is possible to filter suspected persons from those wishing to cross the border with the help of different technical tools. ${ }^{11}$ By the end of the 1980s, several legislative changes occurred to facilitate border crossing which had an impact on the issue of passports, on the travel abroad, and on the crossing of state borders, as well. From the perspective of studying the content changes of border check, it could be valuable to establish whether a particular society has an impact on this factor. In order to make a comparison, without aiming to be exhaustive but taking into account different social conditions, I have chosen the Border Check Order/Command, which was issued for Border Crossing Points (hereinafter: BCP) in 1969 by the Ministry of the Interior, ${ }^{12}$ National Border Guard Headquarters under case number

Selectivity: Means selection, sorting. The activity of the authority responsible for the execution of border traffic control during which the control of persons wishing to cross the state border and, if applicable, the control of the vehicle, consignment in his/her possession or under his/her supervision are conducted based on risk analysis, with the establishment of risk indicators and profiles, taking into account passenger and vehicles categories, generalised criteria, pieces of information and reasons for suspicion. The control is conducted - in a way appropriate to the degree of risk/ threat - based on sorting which is adjusted to the risk classification.

10 Differentiation: Means distinction, making difference. The activity of the authority responsible for the execution of border traffic control during which, beside conducting selective control, such a control is conducted which has a different content, and such control methods, tools and conditions are chosen which are adjusted to the risk classification.

11 Zsigovits (2015)

12 A Magyar Népköztársaság Belügyminiszterének 08. számú Parancsa, Budapest, 1969. évi július hó 23-án. 
ÁBTL -4.2. -10-21/8/1969/2 with HT-4 'Top Secret' ${ }^{\text {'3 }}$ classification which specified the followings with regards to border check:

"The tasks of the TCP14 are:

- to control the travel documents of persons participating in border traffic, to ensure border crossing for those persons who have valid document or permission, to register and report traffic data;

- to detect fake or forged travel documents and their users; to hinder border crossing in case of those persons who have invalid travel documents, do not have travel document or permission due to other reasons, moreover, who wish to cross the border in an improper way, and to apprehend border offenders and their helpers;

- to control vehicles and consignments crossing the state border in order to detect border offenders and prohibited materials;

- to ensure border crossing for military consignments, military persons crossing the state border;

- to perform tasks related to state security assigned to the TCP;

- to issue visa, furthermore, firearms (and munitions) license based on authorisation;

- to protect the location and the places of employment of the TCP;

- to assist the work of the Ministry of the Interior's other agencies and custom offices during border check."

The Border Check Order/Command ${ }^{15}$ currently in force does not contain the definition explicitly because it is defined by the Schengen Borders Code, ${ }^{16}$ and it is directly applicable in Hungary, too. The Order/Command, however, contains the service tasks to be carried out where the followings are specified among those passport control officers' tasks who perform first line control:

- "to ensure the legal border crossing of those persons who wish to cross the border at the border crossing point, to control vehicles and consignments;

- to detect infringing acts and to take the necessary measures;

- to comply with the provisions regulating the order and technology of border check, moreover, to comply with rules related to data protection, accident prevention and cooperation, and

- to perform tasks related to statistics and reporting duty."

Based on the examination of norms regulating the execution of border check, which are just some examples from the past and present but are suitable for comparison, in my point of view, it can clearly be stated that there is no difference regarding the content

\footnotetext{
Az 1995. évi LXV. tv. 28. §-ára figyelemmel a minősítését megszüntették.

TCP: Traffic Control Point.

Az Országos Rendőrfőkapitány 24/2015 (X. 15.) ORFK Utasítás.

16 Regulation (EU) 2016/399 of the European Parliament and of the Council of 9 March 2016 on a Union Code on the rules governing the movement of persons across borders (Schengen Borders Code) (codification). Available: https:// eur-lex.europa.eu/legal-content/EN/TXT/?uri=CELEX:32016R0399 (Downloaded: 15.04.2018.)
} 
elements, the objective is the same irrespective of what a certain society is like. From this perspective, Hungary is ideal as the object/subject of examination. Differences shall be searched for in the content of control and its technical support.

Prior to the Hungarian regime change, the principle of 'total' control applied to border check. "During this period, ensuring security was an almost exclusive requirement. For this purpose, the issue of documents necessary for travelling was bound to strict requirements, furthermore, during state border crossing, everyone and everything were exhaustively and comprehensively controlled, and data were registered." ${ }^{\prime 7}$ The total border check reflected the striking opposition of the two world systems which had formed in the aftermath of World War II.

Today, border check in accordance with the Schengen principles is characterised by the already mentioned selective and differentiated proceedings. By applying these control methods, those control components shall be applied which ensure the expected level of security and do not go further than necessary. The number of content elements and the extent of control are basically determined by the risk level of the classification by nationality which is adjusted to the maintenance of security. Among the factors influencing control the followings could be mentioned:

- in what relation border check is carried out (e.g. on a common border section with a third country or with a state which is an EU Member State but does not have full Schengen membership but has already undergone the Schengen Evaluation);

- what the activity as per committing infringing acts/their real threat in terms of the particular relation/direction is like (including the number of persons illegally crossing the border typically at the green border and the number of irregular migrants too);

- characteristics/opportunities related to the border crossing point (its location, infrastructural accessibility/from solely one or more directions, permeability, technical equipment, preparedness of the staff and their duty discipline);

- passenger traffic (its composition/persons enjoying the right of free movement under Union law, third country nationals/visa-free, subject to a visa requirement, volume);

- content of the cooperation between authorities taking part in border check, consistency of internal regulators, their impact on control;

- impacts of border check-related regulations, norms and introduced restrictive measures on control.

When studying the figures of passenger traffic trends, it can clearly be justified that it is necessary and inevitable to apply selective and differentiated control.

17 Balla (2007) 22. 
Table 1: Passenger traffic trends, 2000-2017. Source: Statistics compiled by the author based on the data provided by the Border Policing Department, Directorate General for Law

Enforcement, Hungarian National Police Headquarters.

\begin{tabular}{|c|c|c|}
\hline Year & Number of persons & $\begin{array}{c}\text { Change (in persons) compared } \\
\text { to the previous year }\end{array}$ \\
\hline 2000 & $87,843,629$ & $+5,425,905$ \\
\hline 2001 & $87,562,205$ & $-281,424$ \\
\hline 2002 & $93,809,467$ & $+6,247,262$ \\
\hline 2003 & $96,829,291$ & $+3,019,824$ \\
\hline 2004 & $104,126,299$ & $+7,297,008$ \\
\hline 2005 & $111,219,066$ & $+7,092,767$ \\
\hline 2006 & $113,135,156$ & $+1,916,090$ \\
\hline 2007 & $117,042,051$ & $+3,906,895$ \\
\hline 2008 & $35,458,676$ & $-81,583,375$ \\
\hline 2009 & $32,897,474$ & $-2,561,202$ \\
\hline 2010 & $33,278,636$ & $+381,162$ \\
\hline 2011 & $34,042,418$ & $+763,782$ \\
\hline 2012 & $33,591,347$ & $-451,071$ \\
\hline 2013 & $34,531,912$ & $+1,391,636$ \\
\hline 2014 & $37,774,508$ & $+3,242,596$ \\
\hline 2015 & $42,225,872$ & $+4,451,364$ \\
\hline 2016 & $50,795,514$ & $+8,569,642$ \\
\hline 2017 & $53,576,495$ & $+2,780,981$ \\
\hline
\end{tabular}

Figures can be examined based on various aspects regarding which I would like to make statements and draw conclusions concentrating on two time spans:

- The first period: The Hungarian EU accession resulted in the fact that traffic 'has been put on a growth path' because in 2007, there was an increase in the number of persons crossing the state border by 12,915,752 compared to 2004 . From the volume of passenger traffic in 2007, 42,272,894 persons travelled through the Hungarian-Austrian border crossing points which represented $36 \%$ of the total traffic (in 1889, 33,049,315 persons crossed the Hungarian-Austrian border crossing points which represented $35 \%$ of the total traffic. It can be concluded that the ratio of the traffic of this relation to the total traffic can be considered stable.) 
- The second period: The period following Hungary's full Schengen membership when a drastic decline in traffic is visible. The reason for this was that 1,111 $\mathrm{km}$ from 2,214.6 km became internal borders and border control was abolished which includes the abolishment of border check, too. In view of this, when studying data from 2007 and 2008 then the decline by 81,583,375 persons shows that almost $70 \%$ of the total traffic - in this case, considering the traffic, like total traffic and traffic of the external border section, of these two years steady - were realised at internal borders. It means that the trends regarding the number of official document forgeries could vary proportionally with the traffic volume, and it may, of course, significantly depend on the composition of traffic by nationality. In the period between 2008 and 2017, a significant increase in traffic can be observed, namely, $+18,117,819$ persons which is an increase by $51 \%$.

- During the practical execution of border check, it plays a crucial role in which country the document, handed over to the person carrying out control by the traveller who wishes to cross the border, is registered and what its type is. This moment is significant not only due to the fact what nationality the person subject to control 'holds' according to the document, but it is also important what type of security features the certain document contains, and what kind of technical background and professional knowledge are required from the person carrying out control in order to check their authentication. These have an impact on the duration of control, and at the same time, on the permeability of a particular border crossing point and the waiting time.

- By the implementation of the 'freedom of movement' provided by the Schengen ideal it shall be meant and we shall suppose that those persons who are 'situated within a certain circle', namely, who are EU citizens - furthermore, those third country nationals who are family members of an EU citizen exercising his/ her right to free movement - shall undergo a more favourable control process in the framework of border check. This results from the fact that he/she is the one whose safety shall be granted against those who are outside this 'certain circle'. Therefore, the control of persons enjoying the right of free movement under Union law carries the lowest security risk. This assumption is partly refuted by the condition that the Regulation (EU) 2016/399 of the European Parliament and of the Council of 9 March 2016 on a Union Code on the rules governing the movement of persons across borders (Schengen Borders Code $)^{18}$ was amended in 2017. This amendment specifies as binding that also this traveller category shall be subject to regular controls in databases. It means that this control had to be introduced at all Schengen external borders of the Member States both on entry and exit. In case of Hungary, the exit at the Hungarian-Romanian and Hungarian-Croatian border section is an exception where it is still possible to carry out non-systematic database controls based on risk analysis. This results from the

18 Available: https://eur-lex.europa.eu/legal-content/EN/TXT/?uri=CELEX:32016R0399 (Downloaded: 15.04.2018.) 
fact that on those border sections of the Member States where the abolishment of border control did not take place but the applicable evaluation process has successfully been closed by the neighbouring state wishing to join the Schengen Area - in case of Hungary, these states are Romania and Croatia - 'systematic' control shall be introduced but at land border crossing points, random controls of persons enjoying the right of free movement under Union law based on risk analysis may also be carried out on exit. It is clear that those persons, whose safety shall be granted within the Schengen Area, shall undergo a stricter check during border check in some respects which is, however, not against but for them, to ensure their safety.

From the perspective of the Schengen Area's security, third country nationals represent a traveller category of higher risk where a line could be drawn between the two levels of threat. Visa-exempt third country nationals represent the first, and third-country nationals subject to a visa obligation represent the second level. It shall be mentioned in these two cases that these nationals must meet the entry requirements ${ }^{19}$ in order to enter the Schengen Area's territory.

In order to cross the state border, one shall primarily have travel documents. The situation was the same, for example, prior to the regime change which I have discussed in more detail in my study. ${ }^{20}$ The control of travel documents is the task of the official who is carrying out control. In particular cases, the security of a certain country or region depends on his/her activities. If he/she is able to identify whether a travel document handed over to control had been altered - had been forged - or had been counterfeited - 'full counterfeit', falsified - or does such a document really exist - is not a camouflage document - then he/she takes actions in order to obtain the goal, namely, to grant security. If he/she is not able to enforce/meet these control requirements and criteria, the control carried out by him/her becomes a security risk.

With regards to the protection system of official documents and from the perspective of the application of security features against forgery, upon the examination of the biodata page of the Hungarian $1984 \mathrm{M}$ passport, ${ }^{21}$ which was valid during the period of the Hungarian regime change, it can be stated following a simple observation that passports were personalised according to the technical and technological development level of that era. Personal data were printed on the security paper itself in a way that they were not even secured by a foil against forgery. Consequently, if this document was subject to forgery, then using the method of erasing/alteration - which could be mechanical or chemical erasing - the alteration of data was quite easy - of course, the

19 Regulation (EU) 2016/399 of the European Parliament and of the Council of 9 March 2016 on a Union Code on the rules governing the movement of persons across borders (Schengen Borders Code) (codification), Article 6. Available: https://eur-lex.europa.eu/legal-content/EN/TXT/?uri=CELEX:32016R0399 (Downloaded: 15.04.2018.)

20 Balla (2017)

${ }^{21}$ The visualisation of the biodata page of the mentioned document can be found in Som (2014). The visualisation of security documents of almost all countries in the world may be found in the Edison document registry system which is available for everyone on the Internet. Available: www.edisontd.net/ (Downloaded: 15.04.2018.) 
number of forgery signs facilitating detection significantly depended on the forgery quality. Contrary to this personalisation, conventionally glued photographs were secured by a wet-stamp imprint and a foil, too against the photo substitution forgery method.

If we examine the biodata page of the Hungarian ordinary passport issued since $2006,{ }^{22}$ it can be seen that the protection system against forgery has reached a level where there is a correlational relationship between the certain security features which means that they are built on each other and a series of forgery shall be committed in order to alter one piece of data. As a result, the number of forgery signs and the chances for detection by the authority increase. Based on these two types of logical reasoning, the consequence may be drawn that basically, those documents become subject to forgery the document protection system of which is on a lower level. Those security documents, which are on the highest level of 'development' regarding document protection, less often become subject to forgery since the chances are minimal that the unlawful/ external interference will not be noticed by the colleagues of the competent controlling authorities.

In all cases, the purpose of official data forgery is to allow such a person to obtain an official document who is not entitled to hold that particular document for any reason. In all cases, the aim is to deceive the controlling officer. When the goal is 'achieved', the person becomes 'entitled', for example, to enter a specific object/building, to cross state borders, to acquire property or even to take out a loan. During border check, one of the aims is to establish whether the person wishing to cross the border holds genuine and valid travel documents.

In my point of view, the professional statement can be accepted as a fundamental thesis according to which as a result of the development of the travel document security features, travel documents may become subject to forgery through more and more qualified forgery methods and processes. In order to enhance the security of the Schengen Area, it is essential to standardise the security features of travel documents which could result in simpler controllability beside the European cohesion. Beside Community interest, of course, national interest shall be taken into account too, and I agree with the following wording: "The protection of official documents, the improvement and maintenance of document security are national interests. The constant development of the most protected official documents, passports and identification documents, furthermore, the elaboration of standard control methods belong to these tasks." ${ }^{23}$ Council Regulation (EC) No 2252/2004 of 13 December $2004^{24}$ was the first to establish the standards for

22 Certain pieces of information concerning the visualisation of the passport may be found on the website of the Banknote Printing Company printing this document. Available: www.penzjegynyomda.hu/fuzetokmanyok/ (Downloaded: 15.04.2018.)

23 Foreword written by Lászlóné Hazai, Som (2014).

24 Council Regulation (EC) No. 2252/2004 of 13 December 2004 on standards for security features and biometrics in passports and travel documents issued by Member States. Available: https://eur-lex.europa.eu/legal-content/EN/TXT /?uri=CELEX:32004R2252 (Downloaded: 14.04.2018.) 
security features and biometrics in passports and travel documents issued by Member States. The making of this regulation was driven by three purposes:

- to make passports more secure through defining standards related to the harmonised security features in a binding way;

- to grant a reliable and direct link between the passport and its owner through the introduction of biometrics;

- to achieve that EU citizens meet the requirements set out in the Visa Waiver Program for the United States of America.

The Regulation lays down also the minimum security standards of travel documents the aim of which is - in addition to developing a standardised appearance and format for the document - to ensure document protection against forgery. The minimum security standards ${ }^{25}$ cover the following components:

- material of the document;

- biographical data page;

- printing technique;

- protection against copying;

- issuing technique.

In order to study the methodological changes in document forgery, it is essential to compile a comparative table. If our aim is to examine the changes in tendencies then, if possible, it is justified to study a time-span as long as possible. The search for data took place through using the sources mentioned in the introduction.

Table 2: Methods of official document forgery detected by the Border Guard (1997-2007) and the Police (from 2008 on), 1997-2017. Source: Statistics compiled by the author based on the data provided by the Border Policing Department, Directorate General for Law Enforcement, Hungarian National Police Headquarters.

\begin{tabular}{|c|c|c|c|c|c|c|c|c|c|}
\hline \multirow[b]{2}{*}{ Year } & \multicolumn{9}{|c|}{ Methods of official document forgery } \\
\hline & $\begin{array}{l}\text { Personal } \\
\text { data } \\
\text { substitu- } \\
\text { tion }\end{array}$ & $\begin{array}{l}\text { Photo } \\
\text { substitu- } \\
\text { tion }\end{array}$ & $\begin{array}{l}\text { Altera- } \\
\text { tion, } \\
\text { erasing }\end{array}$ & $\begin{array}{c}\text { Page } \\
\text { substitu- } \\
\text { tion, } \\
\text { missing } \\
\text { page(s) }\end{array}$ & $\begin{array}{c}\text { Forgery } \\
\text { of visa, } \\
\text { resi- } \\
\text { dence } \\
\text { permit }\end{array}$ & $\begin{array}{c}\text { Forge- } \\
\text { ry } \\
\text { of } \\
\text { stamps }\end{array}$ & $\begin{array}{c}\text { Fake, } \\
\text { ca- } \\
\text { mouflage } \\
\text { pass- } \\
\text { port/ } \\
\text { docu- } \\
\text { ment }\end{array}$ & $\begin{array}{l}\text { Blank } \\
\text { pass- } \\
\text { port }\end{array}$ & Total \\
\hline 1997 & 206 & 1,017 & 632 & 137 & 149 & 127 & 94 & 24 & 2,386 \\
\hline 1998 & 412 & 2,077 & 305 & 113 & 202 & 98 & 101 & 57 & 3,365 \\
\hline 1999 & 335 & 1,462 & 143 & 112 & 241 & 104 & 160 & 47 & 2,604 \\
\hline 2000 & 188 & 1,330 & 141 & 148 & 268 & 78 & 206 & 30 & 2,389 \\
\hline 2001 & 199 & 1,354 & 146 & 125 & 352 & 80 & 128 & 48 & 2,432 \\
\hline
\end{tabular}

25 Ibid. 


\begin{tabular}{|c|c|c|c|c|c|c|c|c|c|}
\hline \multirow[b]{2}{*}{ Year } & \multicolumn{9}{|c|}{ Methods of official document forgery } \\
\hline & $\begin{array}{l}\text { Personal } \\
\text { data } \\
\text { substitu- } \\
\text { tion }\end{array}$ & $\begin{array}{l}\text { Photo } \\
\text { substitu- } \\
\text { tion }\end{array}$ & $\begin{array}{l}\text { Altera- } \\
\text { tion, } \\
\text { erasing }\end{array}$ & $\begin{array}{c}\text { Page } \\
\text { substitu- } \\
\text { tion, } \\
\text { missing } \\
\text { page(s) }\end{array}$ & $\begin{array}{c}\text { Forgery } \\
\text { of visa, } \\
\text { resi- } \\
\text { dence } \\
\text { permit }\end{array}$ & $\begin{array}{c}\text { Forge- } \\
\text { ry } \\
\text { of } \\
\text { stamps }\end{array}$ & $\begin{array}{c}\text { Fake, } \\
\text { ca- } \\
\text { mouflage } \\
\text { pass- } \\
\text { port/ } \\
\text { docu- } \\
\text { ment }\end{array}$ & $\begin{array}{l}\text { Blank } \\
\text { pass- } \\
\text { port }\end{array}$ & Total \\
\hline 2002 & 140 & 782 & 124 & 115 & 326 & 193 & 142 & 17 & 1,839 \\
\hline 2003 & 392 & 731 & 124 & 130 & 717 & 363 & 179 & 29 & 2,665 \\
\hline 2004 & 315 & 820 & 174 & 168 & 1,244 & 428 & 154 & 23 & 3,326 \\
\hline 2005 & 447 & 608 & 217 & 231 & 3,196 & 495 & 216 & 46 & 5,456 \\
\hline 2006 & 327 & 420 & 305 & 237 & 951 & 466 & 470 & 32 & 3,208 \\
\hline 2007 & 253 & 176 & 185 & 72 & 375 & 264 & 928 & 19 & 2,272 \\
\hline 2008 & 32 & 68 & 188 & 30 & 301 & 168 & 488 & 7 & 1,282 \\
\hline 2009 & 47 & 59 & 86 & 18 & 172 & 140 & 526 & 40 & 1,088 \\
\hline 2010 & 53 & 46 & 282 & 24 & 325 & 397 & 128 & 53 & 1,308 \\
\hline 2011 & 75 & 34 & 53 & 18 & 283 & 520 & 447 & 24 & 1,454 \\
\hline 2012 & 40 & 18 & 53 & 9 & 185 & 796 & 387 & 16 & 1,504 \\
\hline 2013 & 56 & 15 & 88 & 24 & 191 & 977 & 421 & 17 & 1,789 \\
\hline 2014 & 77 & 38 & 64 & 31 & 179 & 1,227 & 501 & 23 & 2,140 \\
\hline 2015 & 68 & 43 & 80 & 35 & 145 & 1,308 & 513 & 18 & 2,210 \\
\hline 2016 & 42 & 3 & 77 & 34 & 99 & 1,102 & 492 & 12 & 1,861 \\
\hline 2017 & 98 & 7 & 120 & 15 & 109 & 1,269 & 469 & 57 & 2,144 \\
\hline
\end{tabular}

It is possible to analyse the figures based on various criteria but my intention is to highlight four noteworthy and thoughtful conclusions on a twenty-year timescale which, in some cases, require measure to be taken:

- the number of document content forgery (photo substitution, alteration-erasing, page substitution/missing page) has significantly decreased;

- photo substitution has stopped to be a forgery method;

- the number of personal data substitution has decreased but its ratio to the total number of document forgery shows an increasing tendency again;

- the number of stamp imprint forgery has increased almost twelvefold.

It is important to answer the question: what has the full Schengen membership actually brought for Hungary with regards to document forgery. The answer can be summarised in figures as detailed below:

- the number of document forgery has changed from 2,272 to 1,282 which is a $44 \%$ decrease. In case of this $44 \%$ decrease, the previously mentioned fact shall be taken into account that the volume of total traffic has increased by $70 \%$. Based on this, compared to the 2,272 cases in 2007, the number of detections should 
have decreased by $70 \%$ which means 1,590 cases; and compared to the $30 \%$ ratio of external border passenger traffic, the detection of 682 document forgery cases would have been forecasted in advance. But this is not actually the case. It is not possible to precisely establish data concerning relations and directions based on the available data. But it can be considered a fact that one part of the document forgeries, which were previously detected at the external border on entry, has appeared at the external Schengen border section on exit. In my opinion, the proportion and extent of this decline is therefore not the same as the drop in passenger traffic.

- the number of personal data substitution has drastically decreased by $87 \%$ (-221) from 253 to 32 ;

- the number of photo substitution has decreased by $61 \%$ (-108) from 176 to 68 ;

- the number of erasing-alteration has remained almost the same (+3) from 185 to 188 ;

- the number of page substitution/missing page(s) has decreased by $58 \%$ (- 42) from 72 to 30 ;

- the number of visa and residence permit forgery has decreased by $20 \%(-74)$ from 375 to 301 ;

- the number of stamp imprint forgery has decreased by 36\% (- 94) from 264 to 168;

- the number of fake/camouflage passports/documents has decreased by $47 \%$ ( -440$)$ from 928 to 488 ;

- the number of blank documents has decreased by 63\% (-12) from 19 to 7.

The higher decrease rates of personal data and photo substitution, moreover, the fact that the number of erasing-alteration has remained almost the same despite the $70 \%$ decline shall be considered indicative. The lower decrease rates in the number of entitlement document, visa and residence permit forgeries continue to be significant.

It can be stated that the development of document security features has resulted in a significant tendency shift. There are methods which are almost no longer present and there are such ones which live their 'golden age'. The more secure a document is and the more difficult its forgery is, the more prevalent the personal data substitution method becomes the detection of which depends solely on the identification capabilities of the controlling person until the usage of biometric data does not ensure identification beyond reasonable doubt. It is essential for the controlling staff to be aware of the document forgery tendencies constantly in order to successfully perform their duties.

\section{REFERENCES}

Balla József (2007): A megbízható személyazonosítás, a biztonságos határforgalom-ellenőrzés garanciája. Határrendészeti Tanulmányok, No. 3. 20-24. 
Balla József (2017): A határforgalom-ellenőrzés tartalmi változásai 1990-ig. Hadtudományi Szemle, Vol. 10, No. 2. 295-316.

Pavlik Ferenc - Laky Imre (1907): Határrendészeti Kézikönyv. Budapest, „Pátria” Irodalmi Vállalat és Nyomdai Rt. 404.

Ritecz György (2017): A migráció a XXI. század kezdetén. Saarbrücken, Globe Edit.

Som Krisztián (2014): A magyar úti okmányok 1848-2012. Budapest, Nemzetbiztonsági Szakszolgálat és a Szemere Bertalan Magyar Rendvédelem-történeti Tudományos Társaság kiadványa.

Zsigovits László (2015): Modernkori veszélyek és rendvédelmi robotok. Pécsi Határör Tudományos Közlemények, No. 16. 65-70.

\section{Legal References}

1905. 91.000 sz. B. M. r. a határrendőrségről szóló törvény életbelépéséről és végrehajtásáról. 1905. 91.000 számhoz utasítás a határrendőrségről szóló törvény végrehajtása tárgyában.

A Magyar Népköztársaság Belügyminiszterének 30/1977. számú Parancsa a Határforgalom Ellenőrzési Szabályzat kiadásáról, Budapest 1977. évi október hó 26-án.

A Magyar Népköztársaság Belügyminiszterének 08. számú Parancsa, Budapest, 1969. évi július hó 23-án.

Határforgalom-ellenőrzési szabályzat, az Országos Rendőrfőkapitány 24/2015 (X. 15.) ORFK Utasítása Regulation (EU) 2016/399 of the European Parliament and of the Council of 9 March 2016 on a Union Code on the rules governing the movement of persons across borders (Schengen Borders Code) (codification). Available: https://eur-lex.europa.eu/legal-content/EN/TXT/?uri=CELEX:32016R0399 (Downloaded: 15.04.2018.)

Council Regulation (EC) No. 2252/2004 of 13 December 2004 on standards for security features and biometrics in passports and travel documents issued by Member States. Available: https:// eur-lex.europa.eu/legal-content/EN/TXT/?uri=CELEX:32004R2252 (Downloaded: 14.04.2018.) 